\title{
KEEFEKTIFAN EKSTRAK MENGKUDU PADA BERBAGAI KONSENTRASI TERHADAP PENGHAMBATAN PERTUMBUHAN BAKTERI RALSTONIA SP. SECARA IN VITRO
}

\author{
Efri $^{1}$ dan Titik Nur Aeny ${ }^{1}$
}

\begin{abstract}
Effectivity of Morinda citrifolia extract on in-vitro growth inhibition of Ralstonia sp. Morinda citrifolia has been known as one of plants having numerous medicinal properties. Extract of the fruits shows antibacterial activity against several bacteria including Pseudomonas aeruginosa. The purpose of this study was to observe inhibitor effect of $M$. citrifolia fruit extract, and to investigate the effect of different concentrations of $M$. citrifolia fruit extract on in-vitro growth of Ralstonia (Pseudomonas) sp., the causal agent of banana bacterial wilt disease in Lampung. Inhibition effect of $M$. citrifolia was determined by the presence of inhibition zone, and concentration effect was determined by the diameter of inhibition zone. The study consisted of two experiments. The treatments of the first experiment were three different kinds of fruit extract, namely the whole fruit, the seeds, and the fleshy parts, and the second one consisted of six different levels of extract concentrations. The results showed that the whole fruit extract was the most effective as an in-vitro growth inhibitor, and the higher the concentration level the higher the growth inhibition zone formed.
\end{abstract}

Kata kunci: ekstrak mengkudu, Ralstonia sp.

\section{PENDAHULUAN}

Pisang merupakan salah satu tanaman andalan di Provinsi Lampung, baik sebagai sumber pendapatan keluarga petani maupun sebagai komoditi ekspor. Buah pisang dari daerah ini selain untuk memenuhi kebutuhan pasar lokal juga dikirim ke luar daerah Lampung terutama ke Jakarta, bahkan sampai ke Jepang dan Singapura (Aeny, 1997). Tetapi, pada sepuluh tahun terakhir ini produksi pisang di Lampung telah mengalami penurunan secara drastis yang diakibatkan oleh adanya serangan patogen layu bakteri. Penyakit layu bakteri diketahui sejak tahun 1993, yaitu di sekitar Kalianda Lampung Selatan (Mujim dkk., 1999) tetapi karena penyakit ini sulit dikendalikan maka penyebarannya semakin meluas ke daerah-daerah lain penghasil pisang di Lampung. Dari hasil penelitian Kusumoto et al. (2004), diketahui bahwa penyebab penyakit ini mempunyai kemiripan dengan BDB (blood disease bacterium) dan diidentifikasi sebagai Ralstonia sp. yang merupakan sebutan baru bagi Pseudomonas sp. (Yabuchi et al., 1995). Pada tahun 1988, penyakit darah pada pisang yang ada di Jawa Barat juga dilaporkan sebagai akibat serangan Blood Disease Bacterium (Eden Green and Sastraatmadja, 1990).

Secara umum diketahui bahwa penyakit layu bakteri pada berbagai jenis tanaman, sangat sulit dikendalikan. Beberapa cara pengendalian sudah pernah diteliti tetapi ternyata belum ada yang menunjukkan hasil memuaskan (Aeny, 1999). Pengelolaan penyakit secara terpadu, tampaknya harus dilaksanakan guna menyelamatkan tanaman dari penyakit layu bakteri. Salah satu komponen dalam pengendalian terpadu adalah dimungkinkannya penggunaan senyawa kimia, baik yang sintetik maupun yang non-sintetik yang diperoleh dari bahanbahan tumbuhan. Kesadaran masyarakat terhadap dampak negatif dari bahan kimia sintetik telah mendorong banyak peneliti untuk beralih ke bahanbahan tumbuhan penghasil senyawa beracun atau berperan sebagai pestisida nabati (Kardinan, 2000). Beberapa tumbuhan yang tergolong sebagai pestisida nabati diketahui mengandung senyawa yang bersifat sebagai antimikroba, baik sebagai antijamur maupun antibakteri.

Salah satu tanaman yang diketahui bersifat antibakteri adalah tanaman pace atau mengkudu (Morinda citrifolia). Beberapa macam kandungan senyawa yang dilaporkan berfungsi sebagai zat antibakteri adalah acubin, alizarin, dan antraquinon. Senyawa ini dilaporkan dapat menekan pertumbuhan bakteri Pseudomonas aeruginosa, Proteus morganii, Staphylococus aureus, Bacillus subtilis dan Escherichia coli (Waha, 2001). Dengan khasiat yang dimiliki tersebut, tidak tertutup kemungkinan bahwa mengkudu juga dapat digunakan untuk menghambat pertumbuhan bakteri yang menyebabkan penyakit

\footnotetext{
${ }^{1}$ Dosen Jurusan Proteksi Tanaman Fakultas Pertanian Universitas Lampung, Jl. Soemantri Brodjonegoro, No. 1 Bandar Lampung
} 
pada tanaman atau bahkan menekan perkembangan penyakit yang ditimbulkannya. Oleh karena itu, penelitian ini dilakukan untuk mengetahui pengaruh ekstrak beberapa bagian buah mengkudu dan berbagai tingkat konsentrasinya terhadap pertumbuhan bakteri Ralstonia (Pseudomonas) sp. penyebab penyakit layu pisang secara in vitro.

\section{METODE PENELITIAN}

Percobaan ini dilaksanakan di Laboratorium Bakteriologi dan Nematologi Tumbuhan Jurusan Proteksi Tanaman Fakultas Pertanian Universitas Lampung. Penelitian dilaksanakan dari bulan Maret sampai dangan Desember 2003.

Percobaan terdiri atas dua tahap pengujian. Tahap pertama yaitu pengujian ekstrak beberapa bagian buah mengkudu yang dibandingkan dengan kontrol (air steril) dan bakterisida. Tahap kedua merupakan pengujian lanjutan dari tahap pertama, yaitu bagian buah yang menunjukkan efek penghambatan yang terbaik dari percobaan tahap pertama diuji lebih lanjut dengan membuat beberapa aras konsentrasi yang berbeda.

Penyiapan ekstrak buah mengkudu dilakukan dengan menggunakan blender. Buah yang sudah dipotong-potong diblender sampai halus dan hasilnya disaring. Setelah itu, hasil saringan disentrifus sehingga diperoleh ekstrak/supernatan yang terpisah dari endapan/peletnya. Supernatan selanjutnya ditampung dalam wadah lain lalu disimpan dalam lemari es selama 24 jam.

Inokulum bakteri yang digunakan dalam percobaan ini merupakan oze yang dikoleksi langsung dari tanaman pisang yang terserang penyakit layu bakteri. Selanjutnya oze tersebut ditambah air steril sehingga diperoleh suspensi inokulum bakteri.

Percobaan I. Pada percobaan ini digunakan ekstrak buah utuh, daging buah, dan biji mengkudu. Sebagai pembanding digunakan air steril dan bakterisida. Pengujian kemampuan ekstrak buah mengkudu dalam menghambat pertumbuhan bakteri dilakukan dengan metode bor gabus untuk mengukur zona atau daerah penghambatan yang terbentuk di sekitar tempat aplikasi ekstrak mengkudu. Ekstrak mengkudu diaplikasikan dengan cara mencelupkan cakram media agar ke dalam ekstrak selama 5 menit atau sampai jenuh kemudian cakram media tersebut ditanam pada media yang telah dicampur dengan inokulum bakteri. Pengamatan dan pengukuran zona penghambatan dan koloni bakteri dilakukan setiap hari selama lima hari berturut-turut. Data disajikan dalam bentuk grafik untuk melihat pertumbuhan bakteri selama lima hari inkubasi.

Percobaan II. Pada percobaan kedua ini, diuji beberapa aras konsentrasi ekstrak buah mengkudu utuh, yaitu 0 (air steril), 10, 20, 30, 40, 50, 60, 70, 80, 90, dan $100 \%$. Perlakuan disusun dalam rancangan acak lengkap dengan tiga kali ulangan. Data hasil pengamatan diuji dengan menggunakan regresi linear.

Ekstrak yang akan diuji diaplikasikan pada media agar dengan metode bor gabus, yaitu potongan-potongan media agar berbentuk cakram yang dibentuk dari bor gabus ditetesi dengan larutan ekstrak mengkudu sesuai dengan konsentrasi perlakuan. Masing-masing cakram ditetesi dengan $0.5 \mathrm{ml}$ ekstrak dan didiamkan selama 5 menit supaya meresap. Selanjutnya cakram agar tersebut diletakkan pada cawan petri yang berisi campuran media AGK (agar gula kentang) sebanyak $15 \mathrm{ml}$ dengan suspensi bakteri $R$. solanacearum sebanyak $1 \mathrm{ml}$. Pada masing-masing cawan petri ditanam tiga potongan cakram media agar dan diinkubasi pada suhu kamar selama 24 jam. Pengamatan dilakukan terhadap zona penghambatan yang terbentuk, yaitu daerah bening di sekeliling potongan cakram media karena tidak ditumbuhi bakteri kemudian diukur diameternya.

\section{HASIL DAN PEMBAHASAN}

Hasil pada percobaan pertama menunjukkan bahwa ekstrak buah mengkudu utuh (campuran kulit, daging, dan biji) memberikan efek penghambatan yang paling baik jika dibandingkan dengan kontrol (air steril) maupun bagian-bagian buah yang lain (Gambar 1). Ekstrak buah utuh membentuk zona penghambatan yang paling besar meskipun masih lebih kecil dibandingkan dengan bakterisida pembanding. Hal ini diduga berkaitan dengan ekstrak mengkudu yang diuji masih berupa ekstrak kasar yang mengandung berbagai senyawa lain disamping senyawa yang bersifat antibakteri.

Dari hasil pengamatan juga diketahui bahwa zona penghambatan pertumbuhan bakteri mulai muncul pada hari ke dua. Zona penghambatan merupakan daerah bening di sekeliling cakram media yang tidak ditumbuhi bakteri. Zona penghambatan bertambah besar sampai dengan pengamatan hari ke lima. Dari percobaan kedua dapat diinformasikan bahwa pengaruh konsentrasi ekstrak terhadap zona 


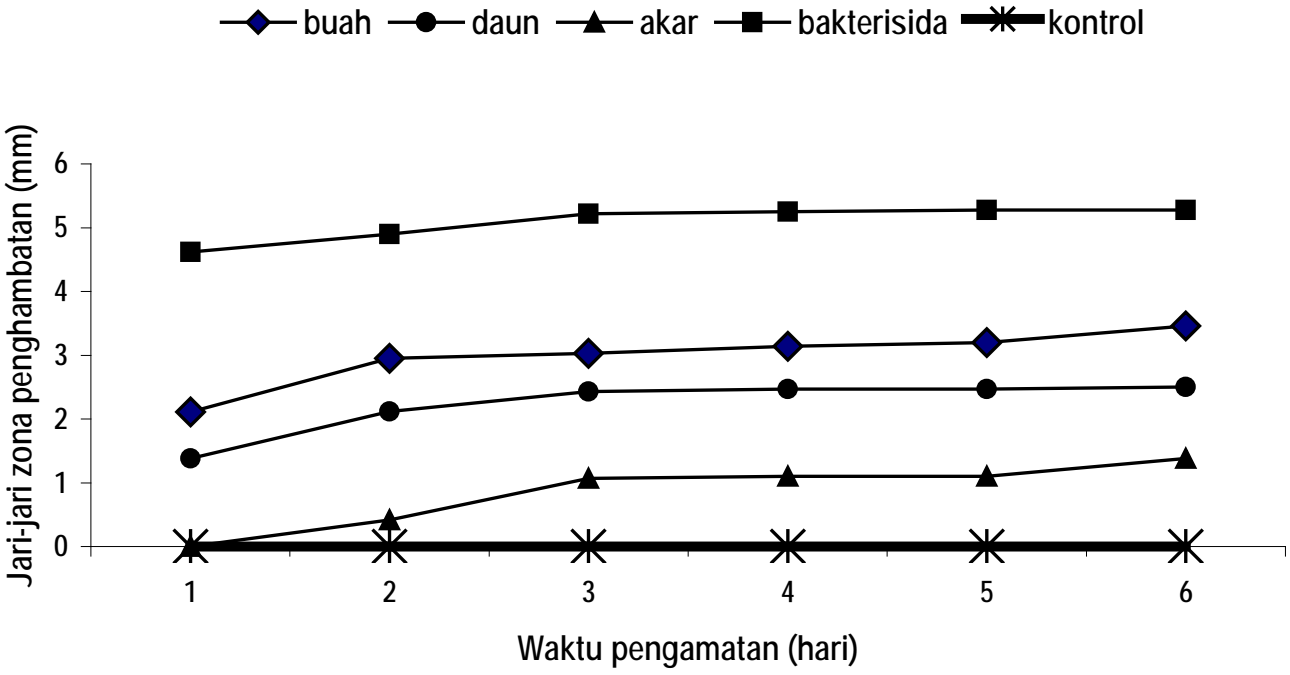

Gambar 1. Grafik peningkatan zona penghambatan pertumbuhan Ralstonia sp. setelah perlakuan ekstrak mengkudu

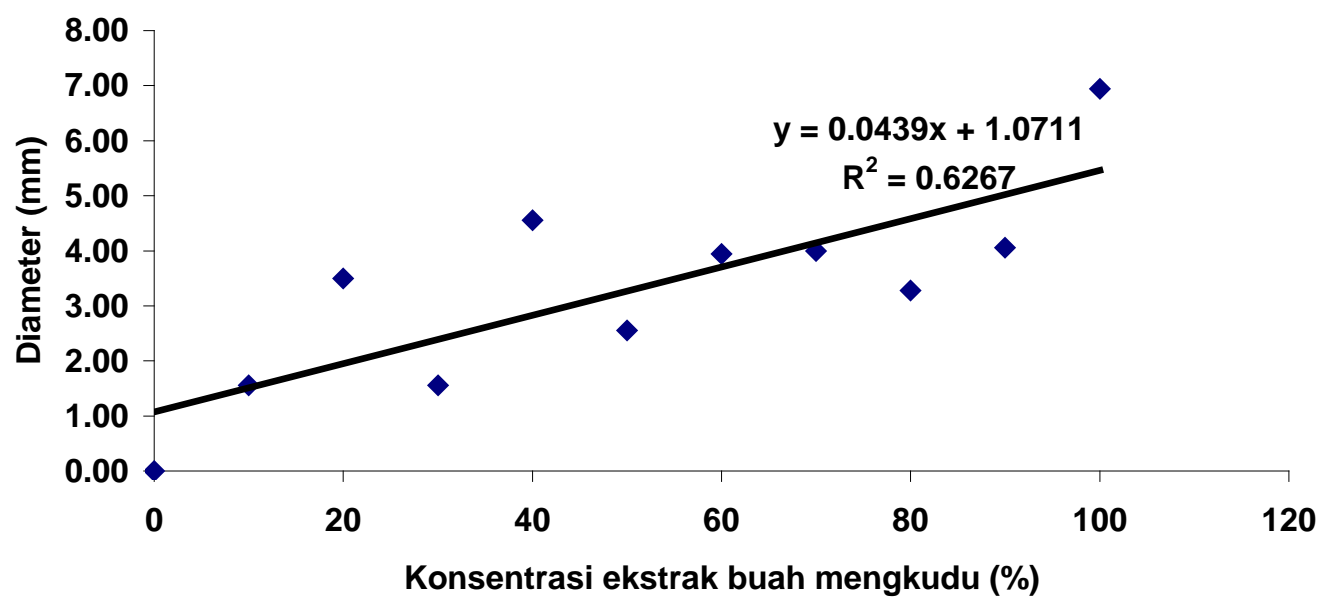

Gambar 2. Grafik diameter zona penghambatan pertumbuhan bakteri Ralstonia sp. pada beberapa aras konsentrasi ekstrak buah mengkudu pada hari ke-2 (data ditransformasi $\mathrm{Vx}+1$ ).

penghambatan terlihat sangat nyata secara linear baik pada pengamatan hari kedua ( $<<0,0027)$, hari ke tiga ( $\mathrm{p}<0,007)$, hari ke empat $(\mathrm{p}<0,0001)$ maupun hari ke lima $(\mathrm{p}<0,0001)$. Sejak pengamatan hari ke dua pengaruh konsentrasi ekstrak terhadap zona penghambatan meningkat secara linear. Semakin tinggi konsentrasi ekstrak semakin tinggi pula kemampuannya dalam menghambat pertumbuhan bakteri Ralstonia sp. (Gambar 2). Pola yang sama juga terlihat pada pengamatan hari ke tiga (Gambar 3), hari ke empat (Gambar 4), dan hari ke lima (Gambar 5). 


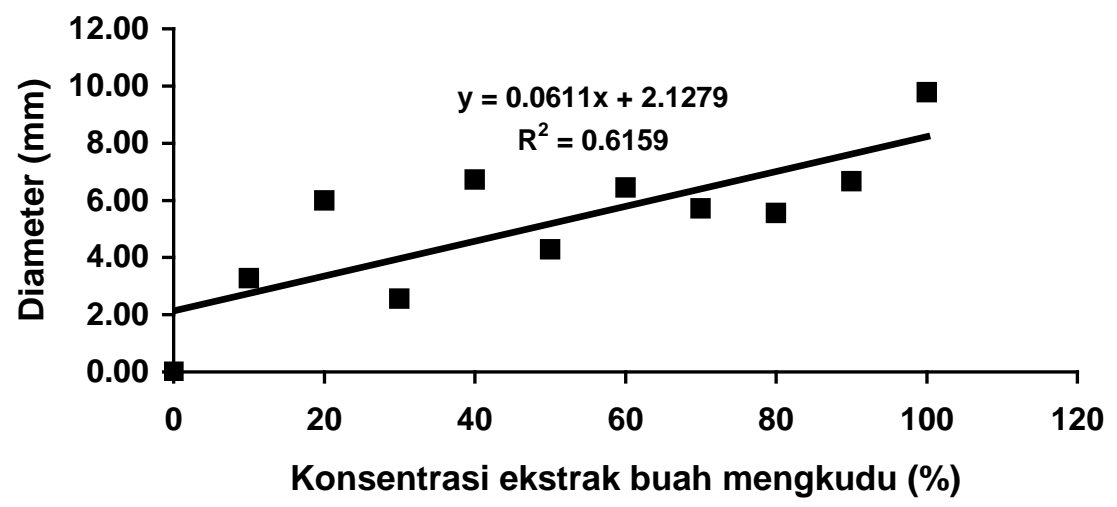

Gambar 3. Grafik diameter zona penghambatan pertumbuhan bakteri Ralstonia sp. pada beberapa aras konsentrasi ekstrak buah mengkudu pada hari ke-3 (data ditransformasi Vx+1).

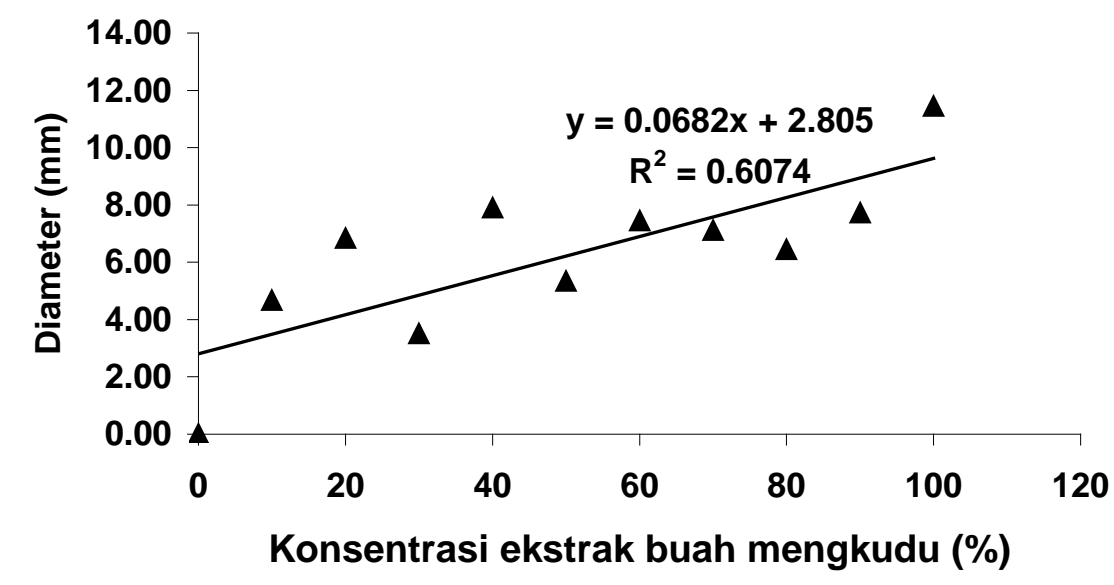

Gambar 4. Grafik diameter zona penghambatan pertumbuhan bakteri Ralstonia sp. pada beberapa aras konsentrasi ekstrak buah mengkudu pada hari ke-4 (data ditransformasi $\mathrm{Vx}+1$ ).

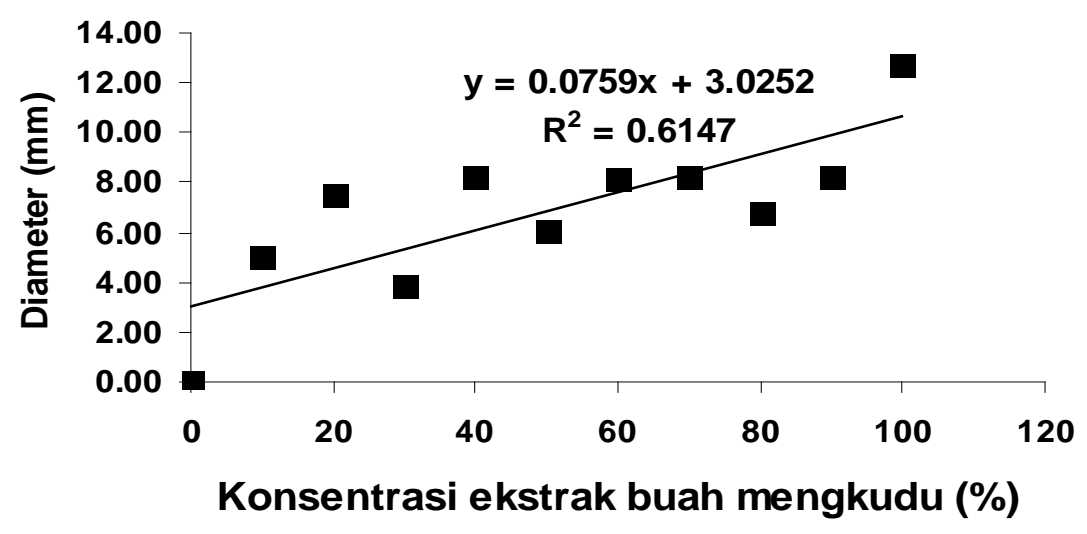

Gambar 5. Grafik diameter zona penghambatan pertumbuhan bakteri Ralstonia sp. pada beberapa aras konsentrasi ekstrak buah mengkudu pada hari ke-5 (data ditransformasi $\mathrm{Vx}+1$ ). 
Dari hasil ini diketahui bahwa ekstrak buah mengkudu mempunyai efek yang cukup baik untuk menghambat pertumbuhan bakteri Ralstonia sp. secara in- vitro dan tingkat konsentrasinya juga mempengaruhi keefektifan penghambatannya. Semakin tinggi konsentrasi ekstrak semakin tinggi pula kemampuan penghambatannya. Proses penghambatan berlangsung sejak dua puluh empat jam dan terus berlangsung sampai hari ke lima, lalu hampir konstan pada hari-hari berikutnya.

Efek penghambatan pada ekstrak mengkudu diduga berkaitan dengan senyawa fenol yang dikandungnya. Volk dan Wheeler (1984) menyatakan bahwa fenol dapat berperan sebagai senyawa antibakteri karena menurunkan tegangan permukaan membran sel yang selanjutnya mempengaruhi protein dan mengganggu fungsinya. Senyawa fenol yang terdapat dalam mengkudu diantaranya adalah antrakuinon, acubin dam alizarin. Ketiga senyawa ini dilaporkan mengandung zat antibiotik (Bangun dan Sarwono, 2002). Dengan konsentrasi ekstrak yang semakin tinggi maka kandungan senyawa fenol ataupun zat antibakterinya juga akan semakin banyak.

Dari percobaan ini, ekstrak buah mengkudu dikatakan dapat bertindak sebagai antibakteri terhadap Ralstonia sp. karena menimbulkan efek penghambatan terhadap pertumbuhan bakteri tersebut. Buah mengkudu, tanpa memisahkan antara daging dan bijinya, akan lebih efektif untuk dimanfaatkan sebagai sumber senyawa antibakteri. Disamping kemungkinan kandungan senyawa aktifnya yang lebih tinggi, penggunaan buah utuh juga akan lebih memudahkan dalam pemrosesannya. Namun demikian, aktivitas senyawa dalam buah mengkudu dan jenis senyawa aktif yang berperan sebagai penghambat masih perlu diteliti dan diidentifikasi lebih lanjut.

\section{SIMPULAN DAN SARAN}

Dari hasil percobaan ini dapat disimpulkan bahwa ekstrak buah mengkudu dapat menekan pertumbuhan bakteri Ralstonia sp. secara in-vitro dengan sangat nyata secara linear. Buah mengkudu utuh (daging dan biji) lebih efektif dibandingkan dengan bagian daging buah maupun bijinya secara terpisah. Tingkat konsentrasi juga berpengaruh nyata, yaitu semakin tinggi konsentrasi ekstrak buah mengkudu semakin tinggi pula kemampuannya untuk menekan pertumbuhan bakteri.

\section{SANWACANA}

Pada kesempatan ini kami menyampaikan terima kasih kepada Universitas Lampung melalui Lembaga Penelitian yang telah memberi bantuan dana. Ucapan terima kasih juga kami sampaikan kepada Sdri. Nova Anggraini, S.P. dan Sdri. Sumiyarti S.P. yang telah membantu pelaksanaan penelitian ini.

\section{DAFTAR PUSTAKA}

Aeny, T. N., S. Mujim, dan Efri. 1997. Intensitas penyakit layu bakteri (Pseudomonas solanacearum) pada beberapa kultivar pisang. Hlm. 467-469 dalam: Parman, ed. Risalah Kongres Nasional XIV dan Seminar Ilmiah Perhimpunan Fitopatologi Indonesia. Palembang 27-29 Oktober 1997.

Aeny, T. N. 1999. Pengaruh bakterisida dan fungisida terhadap intensitas penyakit layu bakteri (Pseudomonas solanacearum) pada pisang. J. Pen. Pengb. Wil. Lahan Kering, No. 22/23: 75-80.

Bangun A.P. dan B. Sarwono, 2002. Khasiat dan Manfaat Mengkudu. Agromedia Pustaka. Tangerang.

Eden Green, S. J. and Sastraatmadja, H. 1990. Blood Disease present in Java. $\quad$ FAO Plant Protection Bulletin 38: 49 - 50.

Mujim, S., T. N. Aeny, C. Ginting, S. Kusumoto, Y. Takikawa, S. Tsuyumu and T. Tsuge. 1999. Bacterial wilt of Bananas in Lampung Indonesia. Page 269-272 In Proceeding of the International Symposium. Asian Natural Environmental Science Center. The United Nation University. Tokyo, 19-20 October 1999.

Kusumoto, S., Titik N. Aeny, Subli Mujim, Cipta Ginting, Takashi Tsuge, Shinji Tsuyumu, Yuichi Takikawa. 2004. Occurrence of blood disease of banana in Sumatera, Indonesia. J. Gen. Plant Pathol. 70:45 - 49. 
Volk dan Wheller. 1984. Mikrobiologi Dasar. Yabuchi, E., Y. Kosako, I. Yano, H. Hotta, and Y. Diterjemahkan oleh Soenartono Adisoemarto. Erlangga, Jakarta.

Waha. 2001. Sehat Dengan Mengkudu (Morinda citrifolia). MSF Group. Jakarta . Nishiuchi 1995. Transfer of two Burkholderia and an alcaligenes species to Ralstonia gen. nov. proposal of $R$. pickettii. Microbiology and Immunology. 39(11): 897 - 904. 


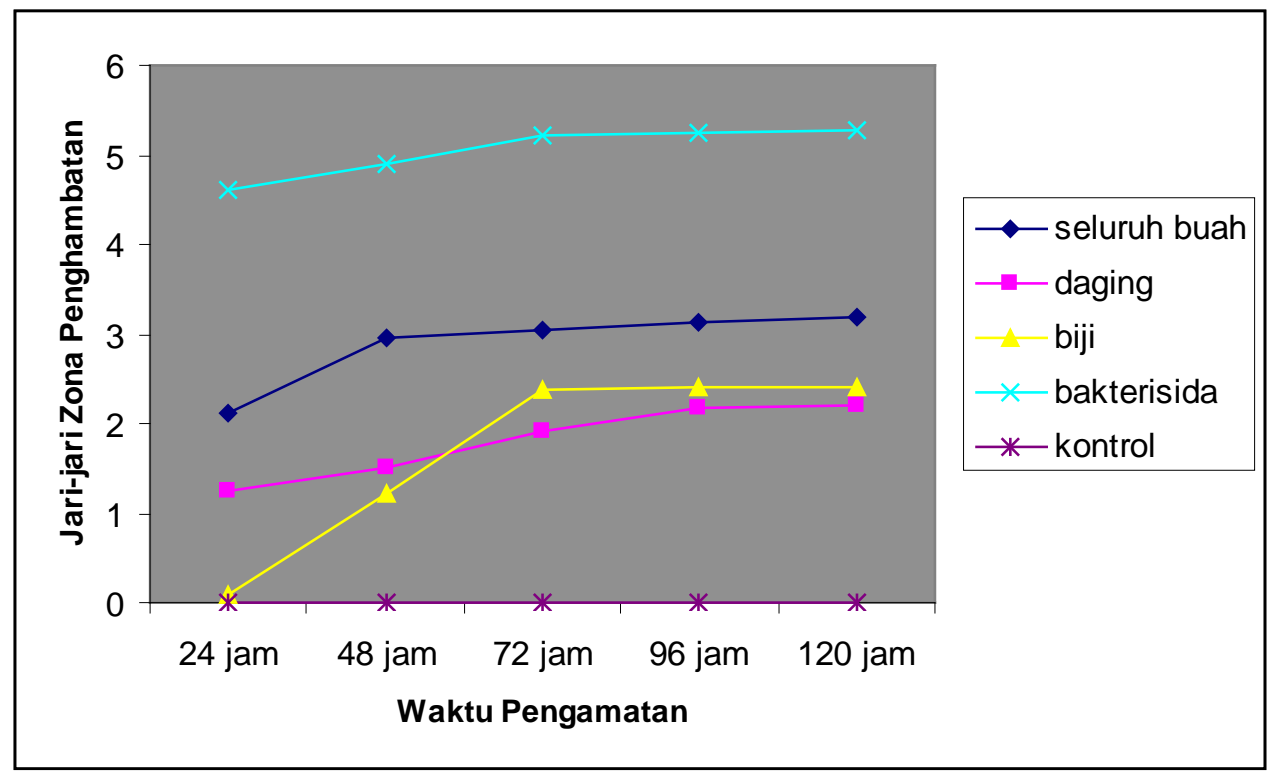

Gambar 1. Grafik peningkatan zona penghambatan pertumbuhan Ralstonia sp. setelah perlakuan ekstrak mengkudu

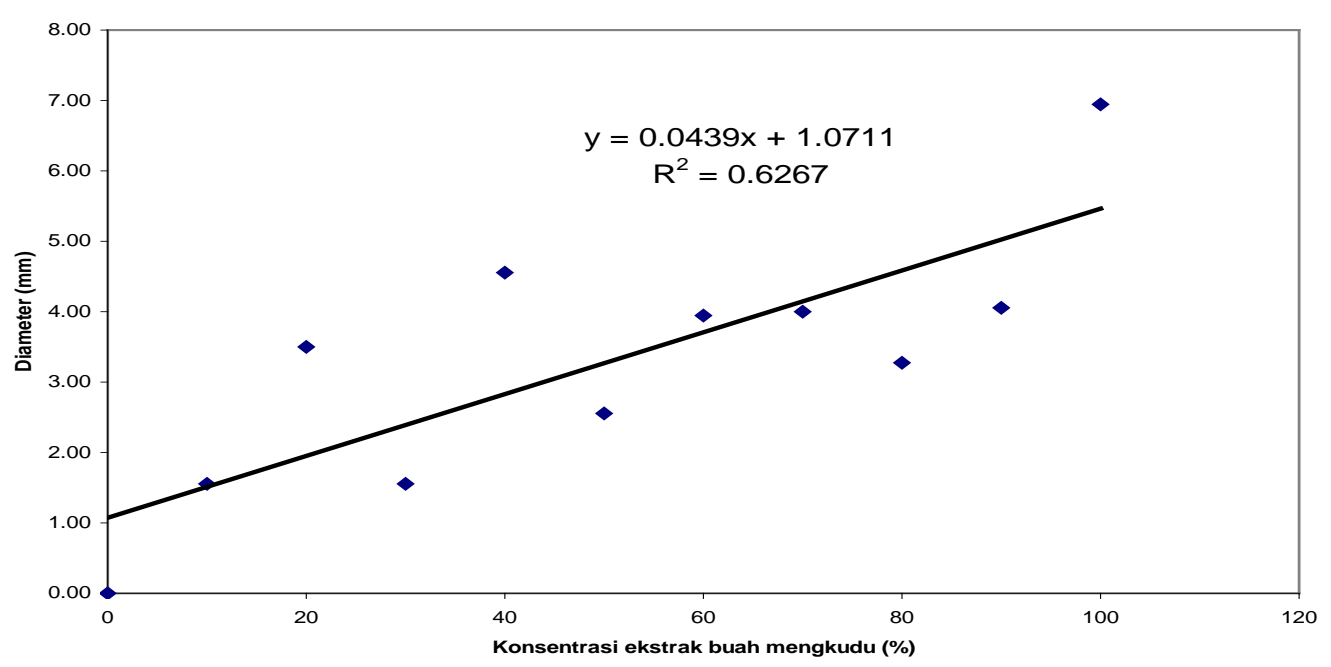

Gambar 2. Grafik diameter zona penghambatan pertumbuhan bakteri Ralstonia sp. pada beberapa aras konsentrasi ekstrak buah mengkudu pada hari ke-2 (data ditranformasi $\mathrm{Vx}+1$ ). 


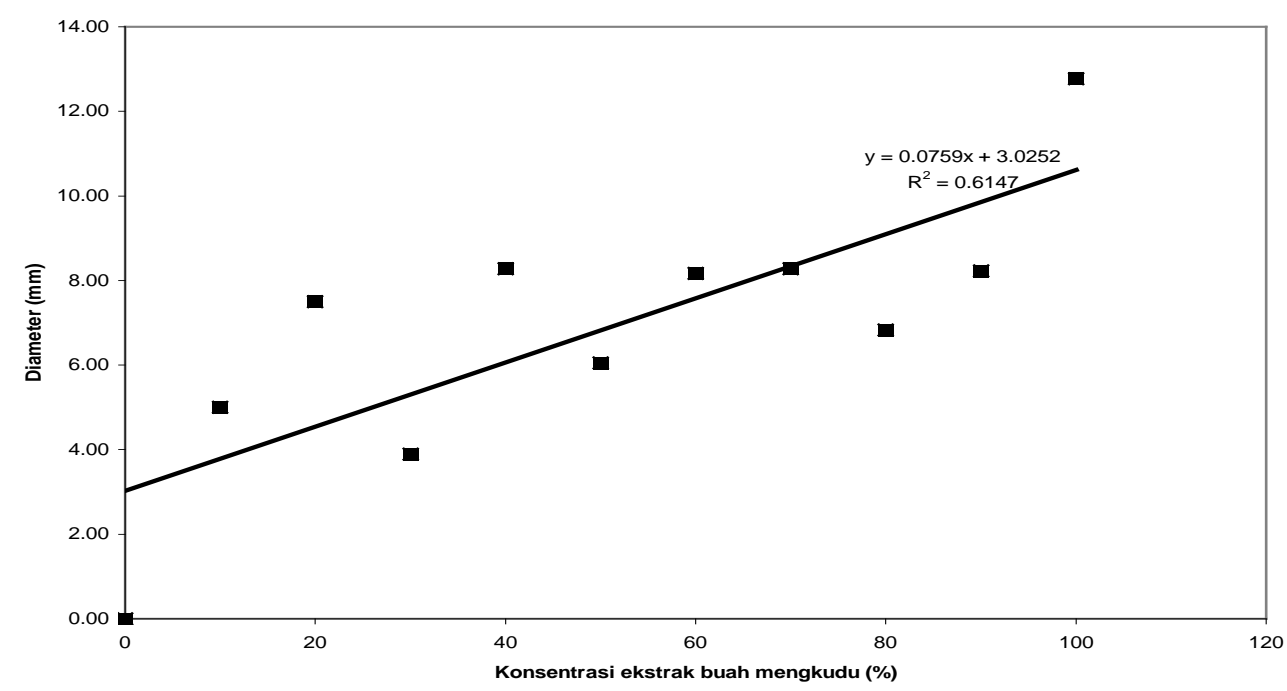

Gambar 3. Grafik diameter zona penghambatan pertumbuhan bakteri Ralstonia sp. pada beberapa aras konsentrasi ekstrak buah mengkudu pada hari ke-3 (data ditranformasi $\mathrm{Vx}+1$ ).

Gambar 5. Grafik diameter zona penghambatan pertumbuhan bakteri

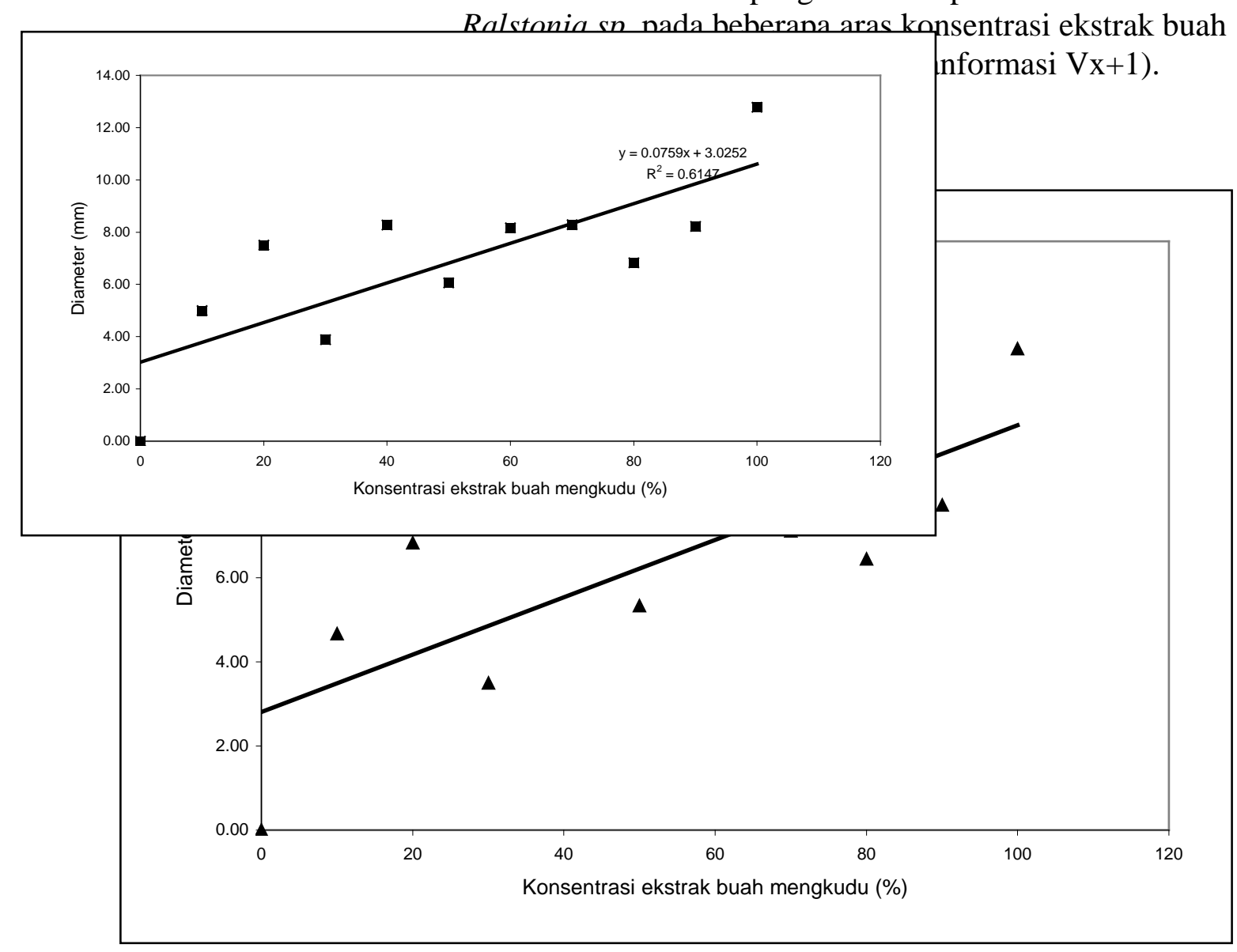

Gambar 4. Grafik diameter zona penghambatan pertumbuhan bakteri Ralstonia sp. pada beberapa aras konsentrasi ekstrak buah mengkudu pada hari ke-4 (data ditranformasi $\mathrm{Vx}+1$ ). 